\title{
DOPUSZCZALNOŚĆ STOSOWANIA TREŚCI \\ O CHARAKTERZE RELIGIJNYM NA INDYWIDUALNYCH TABLICACH REJESTRACYJNYCH POJAZDÓW SAMOCHODOWYCH W POLSCE
}

1. Rejestracji pojazdów samochodowych w Polsce dokonuje się zgodnie $\mathrm{z}$ zasadami kodeksu postępowania administracyjnego ${ }^{1}$ w oparciu o ustawę z dnia 20 czerwca 1997 r. - Prawo o ruchu drogowym² oraz wydanym na jej podstawie rozporządzeniu Ministra Infrastruktury z dnia 22 lipca 2002 r., w sprawie rejestracji i oznaczania pojazdów ${ }^{3}$. Z przywołanych powyżej przepisów prawa wynika, że w Polsce można dokonać rejestracji pojazdu samochodowego w oparciu o indywidualne tablice rejestracyjne dopiero od dnia 21 września 2002 r. Takiej możliwości nie przewidywały poprzednio obowiązujące przepisy prawa polskiego ${ }^{4}$.

${ }^{*}$ Dr hab., Wydział Prawa i Administracji, Uniwersytet Jagielloński, ul. Gołębia 9, 31-007 Kraków, e-mail: zdzislaw.zarzycki@uj.edu.pl

${ }^{1}$ Ustawa z dnia 14 czerwca 1960 r. - Kodeks postępowania administracyjnego (tekst jedn. Dz. U. z 2013 r., poz. 267).

${ }^{2}$ Tekst jedn. Dz. U. z 2012 r., poz. 1137 z późn. zm.

${ }^{3}$ Tekst jedn. Dz. U. z 2007 r. Nr 186, poz. 1322 z późn. zm.

${ }^{4}$ Przedmiotowe rozporządzenie ( $(45)$ uchyliło moc rozporządzenia Ministra Transportu i Gospodarki Morskiej z dnia 19 czerwca 1999 r. w sprawie rejestracji i oznaczania pojazdów (Dz. U. Nr 59, poz. 632, z 2000 r. Nr 25, poz. 305 oraz z 2001 r. Nr 26, poz. 296 i Nr 145, poz. 1632), z wyjątkiem $\S 7$ ust. 2 pkt 1 i załącznika nr 3 w zakresie wzoru pozwolenia czasowego badawczego i wzoru nalepki na tablice tymczasowe, które tracą moc z dniem 31 grudnia $2002 \mathrm{r}$. 
Rejestracji pojazdu dokonuje, na wniosek właściciela, starosta właściwy ze względu na miejsce jego zamieszkania (lub siedzibę osoby prawnej) $)^{5}$.

W celu rejestracji pojazdu jego właściciel, co do zasady, składa w organie rejestrującym tzw. „wniosek o rejestrację” pojazdu, do którego dołącza stosowne dokumenty w tym podanie o indywidualne tablice rejestracyjne ( $\$ 2$ ust. 1 pkt. 1-4 cyt. rozporządzenia).

2. Prawo polskie wśród 6 kategorii tablic rejestracyjnych wymienia tablice indywidualne do oznaczania pojazdów samochodowych (art. 16 pkt 2 cyt. rozporządzenia) ${ }^{6}$. Wielkość, wzór, oznaczenie i kolor takiej tablicy jest znormalizowany. $\mathrm{Na}$ indywidualnej tablicy rejestracyjnej jest wytłoczony numer rejestracyjny barwy czarnej na białym tle, składający się z wyróżnika województwa i indywidualnego wyróżnika pojazdu (§ 18 ust. 4 rozporządzenia) ${ }^{7}$. Na numer rejestracyjny pojazdu składają się litery i cyfry (cyfra) umieszczone na tablicy rejestracyjnej (§ 18 ust. 1 rozporządzenia $)^{8}$. W Polsce obowiązuje zasada, że każdemu pojazdowi przypisuje się jeden niepowtarzalny (indywidualny) numer rejestracyjny ( 18 ust. 1 rozporządzenia $)^{9}$. Należy zauważyć, że prawo

${ }^{5}$ Starosta dokonując rejestracji wydaje dowód rejestracyjny i zalegalizowane tablice (tablicę) rejestracyjne oraz nalepkę kontrolną (art. 73 ust. 1 cyt. ustawy).

${ }^{6}$ Oprócz wspomnianych występują tablice: zwyczajne, zabytkowe, tymczasowe, tymczasowe badawcze i dyplomatyczne.

${ }^{7} \mathrm{Z}$ kolei na tablicy zwyczajnej jest wytłoczony numer rejestracyjny barwy czarnej na białym tle, składający się z wyróżnika województwa, wyróżnika powiatu i wyróżnika pojazdu (§ 18 ust. 3 rozporządzenia).

${ }^{8} \mathrm{~W}$ skrajnej lewej części tablicy umieszcza się dodatkowo, na niebieskim tle, symbol Unii Europejskiej składający się z 12 pięcioramiennych gwiazdek barwy żółtej, ułożonych na obwodzie okręgu, oraz znak z literami „PL” barwy białej (§ 19 ust. 1 rozporządzenia). Na tablicach w miejscu do tego przeznaczonym znajduje się znak legalizacyjny zgodny z przepisami w sprawie legalizacji tablic rejestracyjnych ( $\$ 19$ ust. 2 rozporządzenia). Wzór tablic rejestracyjnych samochodowych indywidualnych jednorzędowych i dwurzędowych określają rysunki nr 29-32 do załącznika nr 8 do cyt. rozporządzenia. Z kolei wzór tablic motocyklowych indywidualnych określają rysunki $\mathrm{nr}$ 40-42 do załącznika $\mathrm{nr} 8$ rozporządzenia.

${ }_{9}^{9}$ Właściciel pojazdu umieszcza na pojeździe tablice $\mathrm{z}$ przodu i z tyłu w miejscach konstrukcyjnie do tego przeznaczonych, z wyjątkiem przyczep, ciągników rolniczych, motocykli i motorowerów, na których tablice umieszcza się tylko z tyłu, z zastrzeżeniem ust. 1a-2 (§ 25 ust. 1 cyt. rozporządzenia). 
zabrania umieszczania na tablicach innych oznaczeń niż te, o których wyraźnie mowa w $\S 18$ i 19 (§ 20 cyt. rozporządzenia) ${ }^{10}$.

Numery rejestracyjne są tworzone z zamkniętego zbioru następujących 25 liter alfabetu (bez polskich znaków): A, B, C, D, E, F, G, H, I, J, K, L, M, N, O, P, R, S, T, U, V, W, X, Y i Z oraz cyfr (arabskich) od 0 do 9 (§ 21 ust. 1 rozporządzenia). Na tablicach indywidualnych - umieszczone są na pierwszym miejscu od lewej strony - litera i cyfra, które stanowią wyróżnik województwa ${ }^{11}$, zaś kolejne litery w liczbie od 3 do 5 stanowią tzw. wyróżnik indywidualny pojazdu. Przy czym nie więcej niż dwie ostatnie litery można zastąpić liczbą (§ 21 ust. 2 pkt 3 rozporządzenia). Organ rejestrujący, co do zasady, wydaje tablice (tablicę) indywidualne, jeżeli identyczne tablice (tablica) nie zostały wcześniej wydane dla innego pojazdu zarejestrowanego na terenie tego samego województwa ( $\$ 24$ ust. 1 cyt. rozporządzenia) $)^{12}$. Organ rejestrujący na wniosek właściciela pojazdu zamiast tablic zwyczajnych w pewnych sytuacjach wydaje zalegalizowane tablice indywidualne (art. 7 ust. 2 rozporządzenia).

Wyróżnik indywidualny pojazdu określa sam zainteresowany właściciel pojazdu, ale w granicach obowiązującego prawa polskiego ( $\$ 24$ ust. 2 cyt. rozporządzenia). Mianowicie prawo polskie przewiduje, że wyróżnik indywidualny powinien stanowić wyraz, skrót lub określenie w języku polskim, niezawierający treści obraźliwych lub niezgodnych z zasadami współżycia społecznego ( $\$ 24$ ust. 3 cyt. rozporządzenia). Ewidencję tablic indywidualnych, wydanych na obszarze województwa prowadzi właściwy miejscowo dla siedziby sejmiku województwa prezydent miasta na prawach powiatu ( 23 pkt 1 cyt. rozporządzenia). Należy zauważyć, że spersonalizowane tablice rejestracyjne wydawa-

${ }^{10}$ Wzory tablic rejestracyjnych, umieszczanych na nich znaków i symboli, a także ich opis określa załącznik nr 8 do rozporządzenia ( $\$ 27$ cyt. rozporządzenia).

${ }^{11}$ Wyróżniki województw i wyróżniki powiatów dla tablic rejestracyjnych określa załącznik nr 7 do rozporządzenia ( $\$ 22$ ust. 2 cyt. rozporządzenia).

${ }^{12}$ Tablice ze względu na wielkość dzielą się m.in. na samochodowe, motocyklowe (dwurzędowe) i motorowerowe (dwurzędowe) (§ 17 ust. 1 cyt. rozporządzenia). Tablice samochodowe mogą być jednorzędowe i dwurzędowe i służą do oznaczania wszystkich rodzajów pojazdów, z wyjątkiem motocykli, ciągników rolniczych, motorowerów i pojazdów rodzaju ,samochodowy inny” (kategorii L6e i L7e). 
ne są na konkretny samochód (lub motocykl albo przyczepę), a nie na jego właściciela i w przypadku wyzbycia się własności auta nie ma prawnej możliwości ich dalszego zatrzymania sobie. Ponadto, opłata za wydanie indywidualnych tablic rejestracyjnych jest znacznie wyższa niż tablic zwyczajnych ${ }^{13}$.

3. Gdyby organ rejestrujący miał wątpliwości co do tego, czy proponowany wyraz, skrót lub określenie pochodzi z języka polskiego i czy nie jest obraźliwe, to może skorzystać np. ze Słownika Języka Polskie$g^{14}$. Prawo administracyjne nie zawiera własnej autonomicznej definicji „zasad współżycia społecznego”. Tym bardziej definicji takiej nie zawiera Prawo ruchu drogowego, o których mowa w $\S 24$ ust. 3 cyt. rozporządzenia. W związku z powyższym należy odwołać się do sposobu rozumienia tej zasady w art. 5 k.c. i linii orzeczniczej panującej w sądownictwie powszechnym i administracyjnym oraz w literaturze przedmiotu.

Otóż w orzecznictwie sądów powszechnych pod pojęciem ,zasad współżycia społecznego", o których mowa w art. 5 k.c. rozumie się pewnego rodzaju wartości uznane w danym społeczeństwie (normy społeczne ogólne) ,odnoszące się do wszystkich możliwych przypadków”. Ponadto, jest „to pojęcie zbiorcze, które obejmuje bardzo wiele klauzul generalnych"15.

Z analizy orzeczeń sądowych wynika, że wielokrotnie starano się ustalić treść zasad współżycia społecznego. Przeważa pogląd, że na tę treść „składają się elementy etyczne i socjologiczne kształtowane przez oceny moralne i społeczne stanowiące uzupełnienie porządku prawnego"16. Innym razem stwierdzono, że zasady współżycia społecznego

${ }^{13} \mathrm{Za}$ wydanie zwyczajnych tablic rejestracyjnych należy uiścić opłatę w kwocie 80,00 zł (za 2 sztuki), zaś za wydanie indywidualnych aż 1.000,00 zł (za 2 sztuki), natomiast tablice indywidualne do motocykla lub przyczepy 500,00 zł (1 sztuka).

${ }^{14}$ Przykładowo, 3-tomowy Słownik Języka Polskiego wydany przez Wydawnictwo Naukowe PWN pod redakcją naukową M. Szymczaka, Warszawa 1996 r.

${ }^{15}$ Wyrok Sądu Apelacyjnego w Poznaniu z dnia 5 lutego 2013 r., sygn. akt I ACa 1151/12, opublikowany w Systemie Informacji Prawnej LEX - Wolters Kluwer SA (dalej: LEX) nr 1292717; wyrok Sądu Apelacyjnego we Wrocławiu z dnia 14 lutego 2012 r., sygn. akt I ACa 19/12, LEX nr 1125305.

${ }^{16}$ Wyrok Sądu Apelacyjnego we Wrocławiu z dnia 13 listopada 1991 r., sygn. akt I ACr 411/91, ,Wokanda” 1992, nr 4, s. 29. 
są ,pojęciem pozostającym w nierozłącznym związku z całokształtem okoliczności danej sprawy i w takim całościowym ujęciu wyznaczają podstawy, granice i kierunki jej rozstrzygnięcia w wyjątkowych sytuacjach, które przepis ten ma na względzie"17. Zamieszczona w $§ 24$ ust. 3 cyt. rozporządzenia klauzula zasad współżycia społecznego „pozwala badać wszelkie relacje międzyludzkie na tle reakcji społecznych i odwoływać się do tych relacji. W sytuacji istnienia konfliktu wartości w zasadzie równorzędnych rzeczą sądu jest wyjaśnienie, którym wartościom i ze względu na jakie okoliczności przyznać pierwszeństwo"18.

Z kolei w orzecznictwie Sądu Najwyższego akcentuje się, że zasady współżycia społecznego pozostają w związku z normami moralnymi ${ }^{19}$. Zdaniem tego Sądu, na treść zasad współżycia społecznego składają się ,akceptowane i godne ochrony reguły rzetelnego postępowania w stosunkach społecznych"20.

Natomiast orzecznictwo Naczelnego Sądu Administracyjnego różnie podchodziło do możliwości stosowania art. 5 k.c. w postępowaniu administracyjnym. Raz wykluczano taką możliwośćc ${ }^{1}$, ale innym razem ją dopuszczano „o ile konkretny przepis prawa materialnego do niego odsyła"22.

Przeciwko pluralnemu rozumieniu zasad współżycia społecznego z art. 5 k.c. wystąpił Trybunał Konstytucyjny w wyroku z dnia 17 października 2000 r., sygn. akt SK 5/99. Zdaniem Trybunału, przesłanki rozumienia klauzuli generalnej powinny mieć wyłącznie charakter obiektywny, a ich interpretacja orzecznicza powinna być ,jednolita i ścisła". Wskazano, że każdy sąd opierając się w swoim orzeczeniu na

${ }^{17}$ Wyrok Sądu Apelacyjnego w Szczecinie z dnia 7 listopada 2012 r., sygn. akt I ACa 580/12, LEX nr 1246858; wyrok Sądu Apelacyjnego w Poznaniu z dnia 15 lutego 2012 r., sygn. akt I ACa 1121/11, LEX nr 1133334.

${ }^{18}$ Wyrok Sądu Apelacyjnego w Gdańsku z dnia 9 października 2012 r., sygn. akt V ACa 704/12, „Przegląd Orzecznictwa Sądu Apelacyjnego w Gdańsku” 2013, nr 1, s. 84-93.

${ }^{19}$ Uzasadnienie wyroku SN z dnia 9 grudnia 2009 r., sygn. akt IV CSK 290/09, LEX nr 560607.

${ }^{20}$ Wyrok SN z dnia 3 lutego 1998 r., sygn. akt I CKN 459/97.

${ }^{21}$ Zob. wyrok NSA w Warszawie z dnia 9 lipca 1998 r., I SA 2224/97, LEX nr 44515.

${ }^{22}$ Wyrok NSA w Szczecinie z dnia 23 maja 1995 r., sygn. akt SA/Sz 347/95, LEX nr 26909 i wyrok NSA z dnia 15 grudnia 1998 r., sygn. akt I SA 649/98, LEX nr 45696. 
zasadach współżycia społecznego powinien wskazać dokładnie, o jaką dokładnie zasadę współżycia społecznego chodzi ${ }^{23}$.

4. W tym miejscu należy zwrócić uwagę na poglądy panujące w literaturze przedmiotu, a odnoszące się do zasad współżycia społecznego. Otóż B. Janiszewska uważa, że zasady współżycia społecznego są „uznawane za najszerszą klauzulę generalną w polskim prawie cywilnym: zarówno pod względem częstotliwości występowania, zakresu sytuacji, stosunków prawnych, w których klauzula ta ma zastosowanie, jak i spectrum wartości, wyznaczających pojemność wywodzonego z niej kryterium oceny („miernika”) zachowania się (...). Zasady [współżycia społecznego] łączą (...) dwie różne sfery wartości. W pierwszej z nich mieszczą się przyjęte przez ludzi, aprobowane normy postępowania, które pozwalają w sposób zgodny kształtować stosunki międzyludzkie, eliminować konflikty. Wyznaczają one wzorzec powinnego zachowania się człowieka $\mathrm{w}$ relacjach $\mathrm{z}$ innymi ludźmi, zakreślając zbiór takich akceptowanych przez ludzi i istotnych dla nich wartości. Podniesienie w konkretnym przypadku zarzutu naruszenia zasad współżycia społecznego wymaga więc dodatkowego określenia, sprecyzowania, przeciwko której z tych ujętych ogólnie zasad zwróciło się działanie lub zaniechanie podmiotu. (...)"24.

Z kolei Z. Radwański stoi na stanowisku, że „Klauzula generalna zasad współżycia społecznego odwołuje się teraz do powszechnie uznanych w kulturze naszego społeczeństwa wartości, które są zarazem dziedzictwem i składnikiem kultury europejskiej"25. W jego ocenie, klauzula zasad współżycia społecznego odsyła do kwalifikowanych norm moralnych ${ }^{26}$.

${ }^{23}$ Krytyczne stanowisko wobec takiego rozumienia zasad współżycia społecznego zajął m.in. L. Leszczyński, Konstytucyjność art. 5 kodeksu cywilnego - tezy Trybunału Konstytucyjnego w świetle teorii prawa, „Kwartalnik Prawa Prywatnego” 2001, z. 3, s. 475.

${ }^{24}$ B. Janiszewska, Pojęcie dobrej wiary w rozumieniu obiektywnym a zasady wspólżycia społecznego, „Przegląd Ustawodawstwa Gospodarczego” 2003, nr 9, s. 2.

${ }^{25}$ Z. Radwański, Uwagi de lege ferenda o klauzulach generalnych w prawie prywatnym, „Przegląd Legislacyjny” 2001, nr 2, s. 11-33.

${ }^{26}$ W.P. Matysiak (Glosa do wyroku SN z dnia 27 czerwca 2001 r., II CKN 604/00, „Przegląd Prawa Handlowego” 2002, nr 8, s. 38-42) uważa, że „Klauzula zasad współżycia społecznego zastąpiła dawne klauzule dobrych obyczajów czy też zwyczajów uczciwego 
Zaś A. Szpunar uważa, że zasady współżycia społecznego są „ogólnie uznanymi normami moralnymi, zawierającymi reguły postępowania między ludźmi ${ }^{27}$. Korygują one we wskazanych przez ustawę okolicznościach treść norm prawnych. Zasady współżycia społecznego są z konieczności pojęciem nieostrym (...)"28.

W. Dajczak stoi na stanowisku, że ,odwołanie się do reguł moralnych pozwala czy wręcz nakazuje poszukiwanie prawdy, dobra, sprawiedliwości przy całkowitym porzuceniu prawniczych wybiegów"29.

K. Piasecki uważa, że zasady współżycia społecznego są pojęciem „pozostającym w nierozłącznym związku z całokształtem okoliczności danej sprawy i w takim całościowym ujęciu wyznaczają podstawy, granice i kierunki jej rozstrzygnięcia w wyjątkowych sytuacjach, które przepis ten ma na względzie. (...) Zasady współżycia społecznego stanowią reguły zachowania się nienormowane co do swej treści przez przepisy prawne (normy prawne). Stanowią one w istocie uzupełnienie porządku prawnego wynikającego z norm prawa. (...) Zasady współżycia społecznego z istoty swej nie nadają się do wyczerpującego skatalogowania" 30 .

obrotu. W pojęciu «zasady współżycia społecznego» mieszczą się bowiem nie tylko pewne reguły postępowania pomiędzy ludźmi, ale również pewne normy moralne (...)”.

${ }^{27}$ Podobny pogląd prezentuje M. Pyziak-Szafnicka, Komentarz do art. 5 Kodeksu cywilnego, LEX, która uważa, że zasady współżycia społecznego są to ,wyłącznie reguły moralne, choć oczywiście nie wszystkie, lecz tylko odnoszące się do stosunków międzyludzkich. Akcent powinien padać, jak się wydaje, na «reguły» zachowania ludzkiego. Niewątpliwie są one wyznaczane przez pewne wartości powszechnie uznawane w społeczeństwie. Przestrzeganie owych reguł spotyka się z pozytywną oceną, jest aprobowane, zaś ich naruszanie jest traktowane jako naganne, spotyka się z dezaprobatą". Podobne w treści stanowisko wyraził T. Sokołowski, Komentarz do art. 5 Kodeksu cywilnego, LEX. Według niego, zasady współżycia społecznego to ,nieskodyfikowane powszechne normy postępowania, funkcjonujące aktualnie w społeczeństwie polskim i mające na celu ochronę społecznie akceptowanych wartości (czyli stanów rzeczy) lub dóbr niematerialnych. Zasady te mają silne zabarwienie aksjologiczne, co zbliża je do norm moralnych, charakter obiektywny, w czym są podobne do zwyczajów, oraz walor powszechności, co odróżnia je od zasad słuszności, które odnoszą się także do indywidualnych, rzadko spotykanych sytuacji”.

${ }^{28}$ A. Szpunar, O zastrzeżeniu nadmiernych odsetek umownych, „Przegląd Prawa Handlowego" 2001, nr 10, s. 34-41.

${ }^{29}$ W. Dajczak, Zasady współżycia społecznego czy dobra wiara, ,Rejent” 2001, nr 1, s. 47.

${ }^{30} \mathrm{~K}$. Piasecki, Komentarz do art. 5 Kodeksu cywilnego, LEX uważa ponadto, że „Nie wystarczy więc powołać się ogólnie na - z natury rzeczy - nieokreślone zasady współży- 
5. Przedmiotowy artykuł ma genetyczny związek ze sprawą administracyjną, jaka toczyła się przed organami administracji publicznej i jednym z sądów administracyjnych w południowej Polsce. Otóż sprawa zaczęła się od wniosku pewnego obywatela uważającego się za „pustelnika” (,syna pustyni”) o imionach T.J. i dwuczłonowym nazwisku T.-M. zamieszkałego w miejscowości S., który w dniu 5 listopada 2008 r. złożył w Starostwie Powiatowym w W. wniosek o rejestrację pojazdu (nazwanego „rydwanem bożym”) marki OPEL (...). Do wniosku obywatel ów dołączył wszystkie wymagane prawem dokumenty oraz podanie o wydanie indywidualnych tablic rejestracyjnych o wyróżniku „K4 JAHWE”.

Decyzją z dnia 19 listopada 2008 r., nr (...) organ I instancji dokonał rejestracji przedmiotowego pojazdu, wydając dowód rejestracyjny seria i nr (...), znak legalizacyjny numer (...) i ,tradycyjne” tablice rejestracyjne (...) oraz odmówił wydania indywidualnych tablic rejestracyjnych, zawierających wnioskowany przez Stronę wyróżnik indywidualny. W uzasadnieniu decyzji wyczerpująco umotywowano swoje stanowisko. Organ ten oparł się na dwóch przesłankach prawnych. Po pierwsze stwierdzono, że ,słowo Jahwe” jest rozumiane jako ,współczesna rekonstrukcja starożytnego hebrajskiego niewymawialnego imienia Boga Izraelitów" i w tym zakresie powołano się na Słownik mitów $i$ tradycji kultury autorstwa Władysława Kopalińskiego, wydanego w Krakowie w 1991 r., s. 417. Uznano tym samym, że słowo „JAHWE” nie jest „słowem, wyrazem lub określeniem w języku polskim”.

Po drugie uznano, że ,wykorzystanie słowa [«JAHWE»] oznaczającego w tradycji judeochrześcijańskiej Boga jako oznaczenie rzeczy codziennego użytku jakim jest pojazd mechaniczny [nawet jeżeli Strona nazwała go ,rydwanem Bożym”], bezsprzecznie sprzeczne jest z zasadami współżycia społecznego". W tym względzie organ ten oparł się na informacjach znajdujących się w Internecie, a w szczególności w internetowej Wikipedii. Stwierdzono, że słowo „JAHWE” „objęte

cia społecznego, lecz należy wskazać jaką przyjętą w społeczeństwie zasadę współżycia społecznego naruszył powód swym postępowaniem wobec pozwanego. Rola zasad współżycia społecznego polega na synchronizowaniu przepisów prawa z nakazami moralności i obyczajów, na uelastycznianiu prawa i zapobieganiu stanom, do których odnosi się znana paremia summum ius - summa iniuria (...)”. 
jest szczególną ochroną zarówno w kulturze i religii judaistycznej, jak i chrześcijańskiej. Począwszy od I w. n.e. w judaizmie przestrzegany jest zakaz używania słowa Jahwe (Wikipedia, http://pl.wikipedia. org.wiki/Jahwe)". Powołano się też na inną informację z tego samego źródła, a mianowicie, że ,we wrześniu 2008 roku Watykańska Kongregacja ds. Kultu Bożego i Dyscypliny Sakramentów na polecenie papieża Benedykta XVI wydała dyrektywę o wycofaniu z tekstów liturgicznych, pieśni kościelnych i modlitw oraz z tekstów i przekładów biblijnych imienia Jahwe, a zamiast tego zaleciła używanie słowa PAN, jako odpowiednika żydowskiego słowa Adonai"31. W związku z powyższym stwierdzono, że ,wykorzystanie na tablicach rejestracyjnych imienia Boga, wspólnego dla większości religii tradycji judeochrześcijańskiej i podlegającego w nich szczególnej ochronie, stanowiłoby naruszenie uczuć religijnych wyznawców tychże religii”.

Odwołanie od przedmiotowej decyzji wniosła strona niezadowolona $\mathrm{z}$ rozstrzygnięcia. W jego uzasadnieniu napisano, że „(...) Role zostały poniekąd odwrócone: To pustelnik jest profanatorem i bluźniercą Imienia BOGA Jahwe, a Brat Starosta Jego wielkim obrońcą i czcicielem i cenzorem religijnym wysokiego stopnia, mocy i władności, godności, odpowiedzialności i uszlachetnienia!!! (...)”. W dalszej części Odwołujący się podnosił, że użycie słowa „JAHWE” na indywidualnej tablicy rejestracyjnej ma na celu jedynie pochwałę imienia BOGA a nie bluźnierstwo i w całej zupełności dopuszczalne jest jego użycie.

Sprawę w dniu 13 lutego 2009 r., znak: (...) rozpoznało Samorządowe Kolegium Odwoławcze w K., które decyzję organu pierwszej instancji utrzymało w całości w mocy. Kolegium uznało uzasadnienie decyzji organu pierwszej instancji za zasadne z uwagi na to, że „umieszczenie wnioskowanego przez Stronę słowa «Jahwe» na tablicy rejestracyjnej stanowiłoby naruszenie regulacji określającej zasady posługiwania się wyróżnikami o charakterze indywidualnym, przewidzianej w treści powołanego wyżej $§ 24 \mathrm{w} / \mathrm{w}$ rozporządzenia z dnia 22 lipca 2002 r. Należy w szczególności zwrócić uwagę, iż niewątpliwe

${ }^{31}$ Dodatkowo powołano się na informację z artykułów zamieszczonych w ,Tygodniku Powszechnym" z dnia 11 września 2008 r., pt. Watykan zmienia imię Boga i Bóg bez imienia. 
sprzeczne z zasadami współżycia społecznego, jako mogące naruszać uczucia religijne, jest umieszczenie na rzeczy codziennego użytku, jaką stanowi samochód, wyrażenia będącego odzwierciedleniem w kulturze judeo-chrześcijańskiej imienia Boga (...). Dodać także należy, iż przedstawienie wnioskowanego wyrażenia jako treści tablicy rejestracyjnej można jednocześnie uznać za realizujące negatywną przesłankę «treści obraźliwych» dla niektórych osób. Kolegium dostrzega, iż w przekonaniu Strony to zestawienie niewątpliwie nie jest obraźliwe i jest dopuszczalne jako stanowiące wyraz afirmacji Boga - niemniej jednak przytoczony przepis rozporządzenia, w którym posłużono się klauzulami generalnymi odsyłającymi do norm pozaprawnych, a który organ administracyjny, zgodnie z zasadą legalizmu określoną w art. 6 kodeksu postępowania administracyjnego, jest obowiązany stosować, nakazuje uwzględnienie także interesów innych osób. Uwzględnienie interesu indywidualnego w tym przypadku może nastąpić jedynie przy jednoczesnym nieobrażaniu uczuć religijnych innych członków społeczeństwa. A contrario, brak poszanowania uczuć religijnych innych osób może się realizować poprzez umyślne działanie polegające na umieszczeniu na pojeździe mechanicznym słów, które podlegają określonym regulacjom restrykcyjnym co do zasad posługiwania się nimi w miejscu publicznym. Tym samym takie zachowanie się mogłoby wyczerpywać znamiona typu czynu zabronionego zdefiniowanego w art. 196 kodeksu karnego [tj. obrazę cudzych uczuć religijnych]. W związku z powyższym zasadnie organ przyjął, iż w sprawie zaistniały negatywne przesłanki, o których mowa w $\S 24 \mathrm{w} / \mathrm{w}$ rozporządzenia i prawidłowo, stosując $\S 7$ ust. 1 rozporządzenia, dokonał legalizacji tablic rejestracyjnych [,tradycyjnych"] przedłożonych przez Stronę (...)"'.

Skargę na powyższą decyzję złożyła Strona wnioskując jednocześnie o zwolnienie jej z uiszczania opłaty sądowej i wyznaczenie adwokata z urzędu. Wojewódzki Sąd Administracyjny w K. zanim rozpoznał sprawę merytorycznie zajął się wnioskami Strony. Postanowieniem z dnia 27 maja 2009 r., sygn. akt III SA/Kr 338/09 oddalono wniosek Strony o zwolnienie od kosztów i ustanowienie adwokata $\mathrm{z}$ urzędu. W ten oto sposób spór główny upadł. 
6. W związku z tym co wyżej napisano, nasuwają się pewnego rodzaju sugestie i przemyślenia co do dopuszczalności stosowania treści religijnych na indywidualnych tablicach rejestracyjnych pojazdów samochodowych w Polsce. Po pierwsze, za niedopuszczalne, bo niespełniające wymogu brzmienia w języku polskim, należy uznać próby użycia obcojęzycznego wyrazu, skrótu lub określenia o charakterze konfesyjnym np.: wyrazu „Bóg” w językach obcych jak „GOD” (ang.), „GOTT” (niem.), „DEUS” (łac.), „DIOS” (hiszp.), „DIO” (wł.), czy też „БОX” (ros.). Z podobnych powodów niedozwolone jest użycie wyrazu „JAHWE” określającego niewymawialne imię Boga w tradycji Izraelskiej, a także wyrazu „Jezus” w językach obcych, jak np. „JESUS” (ang., hiszp., niem.), „IESUS” (łac.) i „GESU” (wł.). Podobnie za niedopuszczalne należy przyjąć próbę umieszczenia wyrazu, skrótu lub określenia w języku polskim, ale zawierającego treści obraźliwe, w tym wulgarne.

Osobną grupę będą stanowiły konfesyjne wyrazy, skróty lub określenia w języku polskim, ale niezgodne z zasadami współżycia społecznego. Moim zdaniem, potencjalne treści o charakterze religijnym na indywidualnych tablicach rejestracyjnych ze względu na ich kolidowanie z zasadami współżycia społecznego można podzielić na dwie kategorie, tj. takie, które w naszej kulturze prawnej powinny być niedopuszczalne, i takie, które powinny być dopuszczalne.

6.1. Jako niezgodne z zasadami współżycia społecznego uznawane będą próby umieszczenia na indywidualnych tablicach rejestracyjnych takich wyrazów, jak imię Boga pozbawione polskiej litery „ó” w określeniu „BOG” (i jego odmiany np.: „BOSKI”, „BOSKA”, „BOSKO”, „BOGU”, „BOGOM”, itd.). Za niedopuszczalne należy uznać próbę użycia słowa „JEZUS”, jako godzącego w wyznawców religii chrześcijańskiej, czy też słowa „ALLAH” godzącego w wyznawców islamu, słowa „BUDDA” czczonego w tradycji buddyjskiej lub słowa „TAO” szczególnie ważnego dla tradycji chińskiej (filozofii taoistycznej).

Sprzeczna z tymi zasadami dla chrześcijanina będzie próba umieszczenia skrótu „INRI” oznaczającego w języku łacińskim Iesus Nazarenus Rex Iudaeorum („Jezus Nazareński Król Żydowski”). Wydaje się, że nie powinno dopuścić się także do umieszczenia skrótu „NMP” 
oznaczającego „Najświętszą Marię Pannę”. Za niedopuszczalne należy uznać próby użycia takich wyrazów, które są stosowane na określenie świętych ksiąg religijnych, jak np. w konfesji muzułmańskiej „KORAN”, w konfesji judaistycznej „TORA”, czy w konfesji i filozofii hinduistycznej „WEDY”. Określenie dnia świątecznego w konfesji judaistycznej - „SABAT ${ }^{\prime 32}$.

Również różnego rodzaju kontrowersje o charakterze $\mathrm{z}$ pogranicza niezgodności z zasadami współżycia społecznego można by uznać próby umieszczenia na indywidualnej tablicy rejestracyjnej wyrazu „AMEN”, czy też imiona papieży np. „PIUS”, „PIUS9”, „PIUSX”, „JAN23”, „LEON9” lub ich skróty np.: „JP2”, „JPII”, a nawet „BXVI" (skrót od imienia Benedykta XVI), a być może że i „FR0” (skrót od imienia obecnego papieża Franciszka). Za niezgodne z tymi zasadami uznane będą próby użycia określenia na oznaczenie duchownego, np. „KLER” lub w konkretnym wyznaniu - np. prawosławnym „POP”, w religii żydowskiej „RABIN”, czy też „CADYK”, a w konfesji muzułmańskiej „IMAM” i ,MUFTI”.

6.2. Za dopuszczalne $\mathrm{w}$ naszej kulturze religijno-prawnej i tym samym niewywołujące większych kontrowersji o charakterze z pogranicza niezgodności z zasadami współżycia społecznego można by uznać próby umieszczenia na indywidualnej tablicy rejestracyjnej imion bogów religii starożytnych, jak np. greckie: „ZEUS” (ojciec bogów), „ATENA” (bogini mądrości), „HERA” (bogini ogniska domowego), „GAJA” (Matka-ziemia), „EROS” (bóg miłości), „TYTAN”, „HADES” (bóg świata zmarłych), „ARES” (bóg wojny). Sytuacja może się zmienić, gdyby polski kierowca samochodu z tak spersonalizowanym wyróżnikiem tablicy samochodowej pojechał do Grecji. Wiadomo, że w tym kraju imiona głównych (dwunastu) bóstw starożytnej religii greckiej są od pewnego czasu pod szczególną ochroną prawną, a religia starogrecka jest jedną z legalnie działających w tym kraju.

${ }^{32}$ Dzień świąteczny w konfesji judaistycznej określany jest także terminem „szabas” lub ,szabat”. 
Za to w naszej kulturze historyczno-prawnej raczej kontrowersji nie powinno wywoływać umieszczenie na tablicy rejestracyjnej wyrazu „MITRA” (wedyjskie bóstwo słońca w dawnej religii Persów), czy bóstw w starożytnych religiach egipskich, jak: „RA” (bóg słońca), „APIS” (święty byk w Memfis), „THOT” lub „THOTH” (egipski bóg księżyca), „PTAH” (bóg stwórca z Memfis), „IZYDA” (bogini płodności), „HORUS” (bóg nieba), „CHNUM” (bóg Górnego Egiptu), „AMON” (bóg urodzaju i płodności), czy też semickie bóstwo „BAAL" lub rzymscy bogowie: „AMOR” (bóg miłości) i „MARS” (bóg wojny).

Za to $\mathrm{w}$ niektórych społecznościach religijnych w naszym kraju kontrowersje może budzić umieszczenie wyrazu „PERUN” określającego przedchrześcijańskie bóstwo Słowian i Bałtów, czczone przez obecnych wyznawców zrzeszonych w neopogańskich związkach wyznaniowych działających w Polsce, np. w Polskim Kościele Słowiańskim oraz Rodzimym Kościele Polskim.

Pewne kontrowersje u wyznawców niektórych Kościołów Wschodnich może wywoływać zbitka trzech szóstek obok siebie na tablicy rejestracyjnej, tj. liczba „666” - z uwagi na to, że jest ona uważana za apokaliptyczne imię Antychrysta ${ }^{33}$. Nie powinno rodzić kontrowersji użycie słowa „LAMA”, oznaczającego godności w religii buddyjskiej.

7. Organy administracyjne dokonujące rejestracji pojazdu muszą działać na podstawie przepisów prawa (art. 8 k.p.a.). Zatem od indywidualnej czujności pracownika takiego organu działającego jednak w granicach uznania administracyjnego ${ }^{34}$ zależy ocena, czy proponowana przez wnioskodawcę spersonalizowana treść tablicy rejestracyjnej jest zgodna z prawem. Wiadomo, że strona niezadowolona z takiej decyzji organu pierwszej instancji może wnieść odwołanie do Samorządowego Kolegium Odwoławczego, a następnie przysłu-

${ }^{33}$ M. Rynkowski, Status prawny kościołów i związków wyznaniowych w Unii Europejskiej, Warszawa 2004, s. 40.

${ }^{34}$ Więcej na temat decyzji podejmowanych w granicach uznania administracyjnego wypowiedział się J. Borkowski, w: B. Adamiak i J. Borkowski, Kodeks postępowania administracyjnego. Komentarz, wyd. 5, Warszawa 2003, s. 486. 
guje jej jeszcze prawo do dwóch instancji sądowo-administracyjnych. Według J. Borkowskiego, sąd administracyjny, który kontroluje decyzję uznaniową, bada, czy na podstawie obowiązujących przepisów prawa dopuszczalne było wydanie decyzji uznaniowej oraz czy przy jej wydaniu organ ,nie przekroczył granic uznania administracyjnego i czy uzasadnił rozstrzygnięcie sprawy dostatecznie zindywidualizowanymi przesłankami" (s. 486). Decyzja uznaniowa powinna być szczegółowo uzasadniona, a w szczególności decyzja negatywna dla strony.

Zachodzi więc pytanie, jakie konkretne zasady współżycia społecznego może naruszać treść napisu na indywidualnej tablicy rejestracyjnej. Pozostając w obrębie treści o charakterze konfesyjnym, wydaje się, że taką wartością, która podlega ochronie może być troska prawodawcy o nienaruszanie cudzych uczuć religijnych. Chodzi tu o dobro osób wyznających jakąś konkretną religię, jak i o osoby niewierzące, które mogą sobie nie życzyć dodatkowych treści o charakterze religijnym w przestrzeni publicznoprawnej. Dla gorliwego wyznawcy katolicyzmu spotkanie na ulicy auta z napisem na tablicy rejestracyjnej np. ,JEZUS” lub „JPII” albo „INRI” może wywoływać zgorszenie, zażenowanie lub co najmniej zdziwienie. Być może, że podobnie zareagowałby muzułmanin na widok rejestracji z napisem „ALLAH” lub „KORAN”, a wyznawca judaizmu na widok tablicy z napisem ,JAHWE”, lub „TORA” albo „RABIN”. Ostrze niezadowolenia może być skierowane zarówno do posiadacza samochodu z taką tablicą, jak i do organu administracji publicznej, który zezwolił na taką rejestrację. Zatem ich naruszenie może budzić określone negatywne postawy u potencjalnego odbiorcy względem posiadacza samochodu z taką tablicą rejestracyjną, a nawet być w skrajnych przypadkach treścią donosów do organów ścigania z powodu naruszenia art. $196 \mathrm{k} . \mathrm{k} .{ }^{35}$

Przy uwzględnianiu tych uczuć należy brać pod uwagę, że pojazd $\mathrm{z}$ takimi tablicami rejestracyjnymi będzie się co do zasady poruszał

${ }^{35}$ Art. 196 ustawy z dnia 6 czerwca 1997 r. - Kodeks karny (Dz. U. Nr 88, poz. 553 z późn. zm.) przewiduje: „Kto obraża uczucia religijne innych osób, znieważając publicznie przedmiot czci religijnej lub miejsce przeznaczone do publicznego wykonywania obrzędów religijnych, podlega grzywnie, karze ograniczenia wolności albo pozbawienia wolności do lat 2 ". 
w określonej przestrzeni publicznej, tj. po polskich drogach publicznych, gdzie będzie obserwowany przez innych uczestników ruchu drogowego i z ich strony można oczekiwać różnych reakcji faktycznych, mogących być niezgodnymi z zasadami ruchu drogowego. Spotkanie kierowcy auta $\mathrm{z}$ takim wyróżnikiem indywidualnym może powodować u innych uczestników ruchu drogowego zachowania z pogranicza prawnie dozwolonych, np. nadmierne skoncentrowanie uwagi na takim pojeździe kosztem wnikliwego obserwowania pozostałych uczestników ruchu drogowego, chęć niedozwolonego wyprzedzenia go, zajeżdżania mu drogi, gwałtownego hamowania przed nim, trąbienia, stosowania znaków świetlnych, czy też manualnego artykułowania różnych gestów i znaków pod adresem kierowcy takiego auta itd. Nie można wykluczyć, że może być narażone „dobro wspólne”, jakim jest troska o własne, jak i cudze życie i zdrowie oraz bezpieczne poruszanie się wszystkich uczestników ruchu drogowego w przestrzeni publicznoprawnej, a w tym przypadku po drogach publicznych (i wewnętrznych także).

\section{BIBLIOGRAFIA}

Adamiak B., Borkowski J., Kodeks postępowania administracyjnego. Komentarz, wyd. 5, Warszawa 2003.

Dajczak W., Zasady wspótżycia społecznego czy dobra wiara, „Rejent” 2001, nr 1.

Janiszewska B., Pojęcie dobrej wiary $w$ rozumieniu obiektywnym a zasady wspótżycia społecznego, „Przegląd Ustawodawstwa Gospodarczego” 2003, nr 9.

Leszczyński L., Konstytucyjność art. 5 kodeksu cywilnego - tezy Trybunału Konstytucyjnego w świetle teorii prawa, „Kwartalnik Prawa Prywatnego” 2001, z. 3.

Matysiak W.P., Glosa do wyroku SN z dnia 27 czerwca 2001 r., II CKN 604/00, „Przegląd Prawa Handlowego” 2002, nr 8.

Pyziak-Szafnicka M., Komentarz do art. 5 Kodeksu cywilnego, LEX.

Radwański Z., Uwagi de lege ferenda o klauzulach generalnych $w$ prawie prywatnym, „Przegląd Legislacyjny” 2001, nr 2. 
Rynkowski M., Status prawny kościołów i związów wyznaniowych w Unii Europejskiej, Warszawa 2004.

Sokołowski T., Komentarz do art. 5 Kodeksu cywilnego, LEX.

Szpunar A., O zastrzeżeniu nadmiernych odsetek umownych, „Przegląd Prawa Handlowego" 2001, nr 10.

\section{ACCESSIBILITY OF USING OF THE RELIGIOUS CONTENT \\ ON THE INDIVIDUAL REGISTRATION PLATES \\ OF VEHICLES IN POLAND}

\section{Summary}

According to the aforementioned legal regulations it results that the Polish legal system allows registration of a vehicle with an individual registration plate from as late as the $21^{\text {st }}$ of September of 2002. The individuality of the registration plates consists in granting by decision of state authority solely letter and number that both constitute the distinguishing feature of each voivodship. The rest of characters in the individual registration plate is specified by an interested owner of given vehicle but always according to the binding Polish law. The regulation in Poland provides that the individual distinguishing feature of the registration plate should consist of word, abbreviation or expression formulated in Polish language of the length of maximally five characters and without any offensive text or content inconsistent with the social co-existence principles. The administrative law does not contain its own autonomous definition of "the social co-existence principles". Therefore, by interpreting of usage of these principles within the administrative law it is necessary to apply the way of understanding of them present in article 5 of the Civil Code altogether with the jurisprudence of the general and administrative courts of law and with the doctrine of the subject. Moreover, the expression "the social co-existence principles" is "joint term which includes numerous general clauses" in connection with the moral norms. In my opinion the potential content of the religious character on the individual registration plates can be divided into two categories on the basis of its collision with the social co-existence principles. The first group contains the examples that are absolutely unacceptable, as for instance: "JESUS", "ALLAH", "BUDDHA" or the abbreviations such as: "JPII", "PIOX", "JOHN23". The second category includes the registration plates that 
contain the content alien to our religious and legal culture, such us: "ZEUS", "ARES", "PTAH". The latter ones are admissible.

Ttumaczenie własne autora

Key words: (individual) registration plates, offence of religious feelings of an individual, the social co-existence principles

Słowa kluczowe: (indywidualne) tablice rejestracyjne, obraza cudzych uczuć religijnych, zasady współżycia społecznego 